\title{
Categories of Intellectual Capital Disclosed by Service-based Companies in Botswana
}

\author{
Byron A. Brown ${ }^{1}$, Afifa Patel ${ }^{1} \&$ Veronica Ofaletse ${ }^{1}$ \\ ${ }^{1}$ School of Business and Leisure, Botswana Accountancy College, University of Derby in Botswana, Botswana \\ Correspondence: Dr Byron A. Brown, Head of the School of Business and Leisure, Botswana Accountancy College, \\ University of Derby in Botswana, Botswana.
}

Received: June 29, 2016

Accepted: July 13, 2016

Online Published: October 28, 2016

doi:10.5430/jms.v7n4p45

URL: http://dx.doi.org/10.5430/jms.v7n4p45

\begin{abstract}
While many service based companies globally have valued and utilised their intellectual capitals to gain competitive advantage, many service-oriented companies in African nations such as Botswana have not done the same. But with the rapid decline in mineral resources in Botswana, and the government's economic diversification drive, service-oriented companies are being encouraged by the government to contribute more to the economy. Weak understanding of the intellectual capitals constrained service-based companies from capitalizing on their assets for competitive advantage or other benefits. Harnessing these assets is critical to business diversification. This study investigated the varieties of intellectual capital disclosed by five service-based companies operating in the Botswana context. Using an interpretive approach, with documents as data sources, we found all three varieties of intellectual capital disclosed: human, structural and relational. The motives for disclosing these assets were linked to factors inside and others outside the companies. But while intellectual capital was disclosed, the reporting was sporadic. The value of intellectual capital that managers articulated in their rhetoric was absent in practice. Various implications are discussed. The study is of benefit to corporate managers, investors, academics and policymakers who are keen about intellectual capital development.
\end{abstract}

Keywords: intellectual capital, service-based company, human capital, relational capital, structural capital, intangible asset, Botswana

\section{Introduction}

While many service based companies globally have valued and utilised their intellectual capitals to gain competitive advantage, many service-oriented companies in African nations such as Botswana have not done the same. But with the rapid decline in mineral resources in Botswana, and the government's economic diversification drive, service-oriented companies are being encouraged by the government to contribute more to the economy. Weak understanding of the intellectual capitals constrained service-based companies from capitalizing on their assets for competitive advantage or other benefits. But one of the challenges that service-based companies face is in clarifying the varieties of their intellectual capital. And the intellectual capital literature has not helped. The literature is divided on the topic. For example, in one strand of literature, intellectual capital is conceptualised as knowledge resources, stored in various forms by a company for its competitive advantage (Lee 2011; Vodak, 2010). In another strand, intellectual capital is conceived of in relation to non-monetary asset, capable of generating future benefits (Choong, 2008; Sullivan, 1998). The OECD (OECD, 2010; 2012) perhaps provides the best interpretation, by defining intellectual capital as the economic value of two dimensions of intangible assets of a company, i.e.: (a) company capital (i.e., structural and relational), and (b) human capital. Thus, intellectual capital may be characterised in terms of a tripartite framework, comprising: human capital (the knowledge, experience, know-how, skills and creativity), relational/external capital (resources that are embedded in external relationships with stakeholders), and structural/internal capital (the processes, systems, intellectual property and infrastructure that a company owns) (FRC, 2014; Brüggen et al, 2009). We took these into consideration when we operationalised the concept, recognizing that it consists of more than one variable, and is not a single, monolithic, concept.

But Pienaar and Du Toit (2009) have stressed that the concept 'intellectual capital' is sometimes perceived as being synonymous with 'intangible assets'. However, the definition offered by the OECD and others (e.g., CIMA, 2009; 
Meritum Project, 2002), makes the distinction clear by anchoring intellectual capital as a subset of, rather than the same as, the overall intangible asset base of a company.

In the context that intellectual capital leads to competitive advantage by virtue of its rare and difficult to imitate nature (Lee, 2011), having an understanding of the stock and categories of these resources is important. Managers of service based companies can better position their firm vis-à-vis their competitors in respect of opportunities in the market, by having deep insights into their categories of intellectual capital and knowing which of these types of resources is appropriate for different business strategy (Subhas \& Vishakha, 2011). Research has demonstrated that reporting on the knowledge based, and on the relationships with customers and suppliers, and the intellectual property and infrastructure assets in the balance sheets places service company managers in a position to give a complete picture of the market value of the company (Meritum Project, 2002).

But there are factors that influence whether and the extent that a company discloses on its varieties of intellectual capital. While it is not compulsory statutorily, to measure and report on intellectual capital (Firer, 2005), market pressures obligate that the varieties of intellectual capital is measured (Subhas \& Vishakha, 2011). The capital market responds positively to a company which reports on its intellectual capital due to uncertainty reduction (Lev, 1999; Subhas \& Vishakha, 2011). Disclosing intellectual capital leads to decrease in a company's cost of capital, and an increase in intrinsic value (Edvinsson \& Malone, 1997; Stewart, 1997). Mundi (2014) found that when the intellectual capital of the company is disclosed, investors tend to pay higher value for its share value. Carrell (2007) illustrated that growth, profitability and global expansion result from placing emphasis on intellectual capital disclosure. Thus, there are fundamental triggers that underpin whether or the extent that intellectual capital is disclosed.

But within the context of financial reporting and corporate disclosure, and the growing emphasis on the knowledge economy, the authors have observed that the majority of intellectual resources are not disclosed in the traditional balance sheets (Lee, 2011; CIMA, 2009; Meritum Project, 2002). For this reason, Lev and Zarowin (1999) observe that the value relevance of traditional annual reports has declined. There is pervasive and mounting frustration with traditional financial reporting. The frustration has manifested in various reports such as the 'Jenkins Report' (AICPA, 1994), the work of Wallman $(1996,1997)$, and recently, the report by both the Accounting Standard Board (2002) and the Canadian Institute of Chartered Accountants (2001). These reports have all affirmed that the traditional financial reporting system is unable to account for 'new' critical resources such as intangibles generated internally, including expertise, experiences, and alliances, and the reporting system is incapable of showcasing intellectual capital as valued asset, rather than as goodwill.

But three changes were made in the International Financial Reporting Standards (IFRS, regulation 3) in response to criticisms about the exclusion of intellectual capital in annual reports, but these changes have been limited to business combination: (a) no more pooling of interests as an accounting method; (b) test goodwill for impairment annually; goodwill can no longer be amortized; and (c) the recognition of intangible assets, even if they previously have not been recognized when they are significant to the acquirer (Singh \& Kansal, 2011). Thus, IFRS-3 allows for the identification, recognition, and valuation of intangible assets (Brannstrom \& Giuliani, 2009). While these changes represent a gradual shift from the total exclusion of reporting on intellectual capital in annual reports, mangers have started to use them as justification for disclosing on intellectual capital, even in business situation that is not combined (Kianto, Hurmelinna-Laukkanen \& Ritala, 2010).

According to the literature, studies with some direct focus on the service sectors have been done. We found ten after a basic library search of major scholarly databases. Engstro"m, Westnes and Westnes (2003) explored intellectual capital in the hotel sector; while Bontis and Fitz-enz (2002) investigated human capital in companies trading in financial services. Roodt (2011) assessed intellectual capital, overall, in South African banks, while Ordonez de Pablos (2004) studied relational capital in banks in Spain. Chang and Birkett (2004) examined competency management in services companies. On the other hand, Namasivayam and Denizci (2006) explored the role that human capital play in service companies. Lim and Dallimore (2004) zoomed into the attitudes of management towards intellectual capital in service companies. Two of the studies we found had samples drawn from the service and non-service sectors. Bontis, Keow and Richardson (2000) assessed the accumulation of intellectual capital in service vs non-service companies in Malaysian, whereas Kianto et al (2010) discussed the main differences in intellectual capital mechanisms - for stocking, creating, managing and protecting these assets - in service-oriented and product-oriented companies. While all these studies are important, they downplayed the aspect of how service companies in emerging African economies deal with the question defining their intellectual capitals. 
A study by Carrell (2007) in the USA investigated service and non-service industry executives to understand how they value their intellectual capital and the reasons thereof. She wanted to find out whether the gap has narrowed between the sentiments of executives, and what theory on intellectual capital reveals. Results indicated a gap between CEOs, CFO and HR executives' definition of company intellectual capital, and what these executives demonstrated in practice. Carrell further reported that all the executives struggled to specify their actual intellectual capital, though they were well aware of its value. This latter result supports the suggestion that managers may find it a challenge to categorise their types of intellectual capitals if they are unaware of how to define and measure such capitals.

Roodt (2011) study of executives in a multinational South African bank is instructive. Roodt (2011) study of executives in a multinational South African bank is instructive. Roodt was interested in whether the executives perceived that their intellectual capital characteristics contribute to competitive advantage in their business. Results showed that while a variety of intellectual capitals was visible across the various business units in the bank, and while executives in all the job categories were unanimous that structural capital, specifically brand, and a conducive working environment, were important factors in remaining competitive, the major challenge that the bank had was that the intellectual capital characteristics were not tracked or measured. The study reported that executives in different job categories stressed different aspect of intellectual capital as important: risk management stressed the instrumental value of intellectual capital, whereas client facing executives stressed human capital as key to competitive advantage. Service based companies may differ within, and/or across company-type, in their outlook and reporting of components of intellectual capital. Further study needs to be done to explore and clarify some of the issues raised above.

\section{The Purpose of the Study}

This study investigated the varieties of intellectual capital in service-based companies in Botswana, and the motives that underpin the disclosures. The implications for disclosing the intellectual capital are also explored.

\section{Background to the Study}

Botswana is transforming its economy from an agrarian and mining economy to a knowledge-based economy (MoESD, 2008), spurred by a drastic reduction in diamond deposits and a decline in primary agricultural production (Ezekwesili, 2012). The country is pursuing a policy of economic diversification in which the service sector is positioned to play a central role. In Botswana, the service sectors are very diverse, ranging from small sectors such as cultural and sporting, environmental and recreational services, which make a negligible contribution to GDP and to employment, to largescale sectors such as construction, transport, educational, distribution, tourism/hospitality, and financial services which make a significantly high contribution to GDP and to employment (BITC, 2014; Willem te Velde \& Calì, 2007). But despite the range of service sectors, only two of these sectors - from the perspective of the Government of Botswana - are paramount because of their export potential, namely: (a) financial services, and (b) tourism/hospitality services (BITC, 2014).

The importance of the tourism/hospitality and the financial service sectors in Botswana are underlined by their relative contribution to GDP and employment. Tourism/hospitality is the service sector that has the highest current exports (WTTC, 2014), and the financial service sector has a high prospect for exports (Mundi, 2014). In Botswana, report shows that the share of tourism/hospitality services to GDP rose from five (5) percent in 1997 to over 8.4 percent in 2013, and is forecast to rise to 10.2 percent by 2024 (WTTC, 2014). The same report (WTTC, 2014) further illustrates that in 2013, the total contribution of tourism/hospitality to employment, including jobs indirectly supported by the sector, was 9.9 percent of total employment (67,000 jobs), and this is expected to rise to 11.3 percent of total jobs by 2024 (89,000 jobs). A study by the African Economic Outlook (AEO, 2012) cites evidence that financial services contribution to GDP in Botswana rose from 6.2 percent in 2006 to 7.4 percent in 2011; and in 2014, the contribution stood at 12.2 percent. These sectors in Botswana, as elsewhere in the world including Europe (e.g., UK [Banking] and Greece [Tourism]) and the Caribbean (e.g., Jamaica and Barbados [Tourism]), comprise an increasingly larger proportion of productive activities that are crucial for economic growth.

Intellectual capital resources and capabilities are essential assets in the services industry (tourism/hospitality and financial included), and Kianto et al (2010) suggest that this importance is borne out by three key indicators: (a) close interaction between service supplier and customers in co-producing the service; (b) the multi-faceted nature of the knowledge created and exchanged (heterogeneity); and (c) the combination of knowledge into useful systems and processes, which is simultaneously exchanged. Service companies then are critically dependent on knowledge works. The human capital aspect of intellectual capital is thus a pivotal component in knowledge works and it is the basis for creating other forms of intellectual capitals such as relational and structural capital (Roodt, 2011; Lee, 2001). In 
Botswana where the aspect of automation of services is still underdeveloped, the provision of service is labour intensive, and it demands real time knowledge works and skills - much of which is tacit knowledge (Kianto et al, 2010). People, as the backbone of tourism/hospitality and financial services creation and delivery in Botswana, form an important $\operatorname{cog}$ in the wheel of intellectual capital and services. The sustainability of the tourism/hospitality and financial services companies hinges on a much deeper understanding of the categories of intellectual capital that they possess.

In terms of regulation, service based companies in Botswana rely on the Botswana Companies Act (Cap 42:01) for guidance in the preparation, presentation, and publication of financial statements - making disclosure and the auditing of their books mandatory (Lekone \& Mukuna, 2014). The same study by Lekone and Mukuna further asserts that the revised Companies Act of 2003, mandates that the preparation of a company's financial statements must conform fully to the IFRS standards. The study found that publicly traded companies and banks subscribe to and follow IFRS, alongside the Botswana Company Act, to prepare, present and publish their financial statements. The study also corroborates report propagated by the Botswana Institute of Chartered Accountants (BICA, 2014) that listed companies on the Botswana Stock Exchange are required to submit annual financial statements, and that these are required to be prepared in conformity with IFRSs. Thus, managers of service based companies have the scope to disclose on their intellectual capital, in alignment with, and/or influenced by, IFRS-3. But they may also want to disclose on these assets to showcase their attempt to support the government's service sector development agenda, or to drive their own business interest.

Nevertheless, the literature on the motive underpinning varieties of intellectual capital disclosure in Botswana is scanty, and studies on the topic tend to mention it in passing or treat it fragmentally. The authors found for example a study by Lange (2004) which explored and contrasted examples of wealth, natural capital and sustainable development between Botswana and Namibia. While the study was based on data not normally covered in measures of intellectual capital overall, the author lamented the lack of data particularly on natural and human capital to execute her research. Although Lange (2004) mentioned human capital in her study, it was not the main thrust, and critical measures of intellectual capital such as structural and relational capital were excluded. Though this study measures aspect of human capital, it is not a substitute for direct measures of intellectual capital, based on data from service based companies.

A study by Msweli (2015) focused only on the human capital element, with emphasis on Botswana and South Africa. She wanted to understand the factors that contribute to differences between Botswana and South Africa on key human capital indices. Msweli did not locate her study within the tourism/hospitality and/or banking service sector or in any other organisational context, and she only looked at human capital as a target for investment through education and training, as opposed to it being utilized as a production element, which can generate added value (Kwon, 2009). While service sector managers in tourism/hospitality and financial services stress intellectual capital in rhetoric, the dearth of empirical work noticeable in the literature suggests that there is a great need for studies that clarify the varieties of intellectual capital disclose in these companies. Based on the above, this study sought to investigate two issues:

a) The varieties of intellectual capital assets disclosed (voluntarily or otherwise) by listed service based companies, and the motives underpinning this disclosure; and

b) The implications for disclosing on the intellectual capital in these companies.

A description of the methodology followed in order to attain these gaols is outlined in the next section below.

\section{Methodology}

Methodological orientation: The study investigated varieties of intellectual capital in service based companies. To do this, the author relied on direct measures of intellectual capital (Guthrie et al, 2004), accessed through documents in the form of the company annual reports. Consequently, the philosophical orientation of this study was qualitative (Creswell, 1994). Specifically, the investigation was guided by a case study design, which allowed for the use of annual reports from multiple service based companies (Merriam, 1998; Creswell, 1994). Yin (2009) maintains that it is pertinent to adopt the case study approach in instances where the focus of the inquiry is to produce a deep understanding or insightful appreciation of the case. This criterion corresponds to our intention which is to draw out insights on the varieties of intellectual capital that exist among the companies. In the circumstances, intellectual capital was the contemporary phenomenon of interest or the case (Yin, 2009).

Secondly, the service-based companies were incorporated as holistic settings that contained the case of inquiry. Each company was treated as being, and as having, a case (Merriam, 1998). Thus, the inclusion of different companies 
meant that the inquiry involved multiple cases. The author opted for a multiple-case approach for two reasons. First, the authors wanted to establish whether varieties of intellectual capital existed across the different service company contexts, and in what relative form and manner. Second, the authors wanted to improve the certainty of our findings by involving more than one case (Yin, 2009). Confidence in our findings is enhanced by including multiple cases (Yin, 2009).

Case selection: The sample of cases was taken from companies listed on the Botswana Stock Exchange, Botswana. Listed companies are obligated to make their annual report public. The authors chose three distinct service-based companies, focusing specifically on companies that operated in the sector of: travel/tourism, hospitality, and financial services. These sectors were leaders in terms of contribution to GDP and employment in Botswana, and thus represented typical cases. The specific companies selected were: (a) Tourism Travel Agency; (b) 5-Star Hotel business; and (c) three companies in financial services: Merchant, Commercial, and Regional Bank. Except for the fact that the companies were all service based, the five companies were quite distinct in terms of their core business (see Table 2). The majority of service based companies in Botswana operated in these distinct sectors (BITC, 2014). As of 2015, there were 14 banks in operation in Botswana, and over 100 microfinancial and related nonbanking institutions. Many of these however are not listed on the Stock Exchange. Likewise, there were over 300 lodges/hotels in the country but only four had five star status. In 2015, there were less than 35 travel agenacies in Botswana. Five service-based companies were selected as cases for the present investigation. While there are no 'fixed' rules on sample size in qualitative inquiry, Yin (2009) maintains that a sample of five cases is suitable for a qualitative inquiry which sought merely to understand a phenomenon. The five companies were selected conveniently, based on (a) the willingness of the companies to participate in terms of consenting to share company specific characteristics and their annual reports, and (b) regardless of whether they had business combination or not. We selected companies that were listed on the Botswana Stock Exchange on 01 April 2014, with fiscal year ending 31 March 2015.

Data collection: Documents in the form of company annual reports were the main data sources. The annual reports were for the financial year ending 31 March 2013, and 31 March 2015. The IFAC Guidelines (1998) which classify intellectual capital guided data collection in terms of disaggregating the varieties of these capitals. This framework was deemed superior to others because it comprises distinctly defined items within the intellectual capital dimensions. The categories used are: (a) human capital: the knowledge, experience, know-how, skills and creativity that employees possess; (b) relational capital: resources that are embedded in external relationships with stakeholders, plus the views of stakeholders about the company; and (c) structural capital: the processes, systems, intellectual property and infrastructure that a company owns, plus organizational routines, procedures, systems, cultures, databases and so on (See Table 1).

Table 1. IFAC (1998) classification of intellectual capital

\begin{tabular}{|c|c|c|c|}
\hline \multirow{2}{*}{$\begin{array}{l}\text { Human capital } \\
\text { 1. Know-how }\end{array}$} & \multicolumn{2}{|c|}{ Structural capital } & \multirow{2}{*}{$\begin{array}{l}\text { Relational capital } \\
1 . \text { Brands }\end{array}$} \\
\hline & A. Intellectual property & B. Infrastructure assets & \\
\hline 2. Education & - Patents & - Financial relations & 2. Customers \\
\hline 3. Vocational qualification & - Copyrights & - Management philosophy & 3. Customer loyalty \\
\hline 4. Work-related knowledge & - Design rights & - Corporate culture & 4. Company names \\
\hline 5. Occupational assessments & - Trade secrets & - Management processes & 5. Backlog orders \\
\hline 6. Psychometric assessments & - Trademarks & - Information systems & 6. Collaborations \\
\hline 7. Work-related competencies & - Service marks & - Networking systems & 7. Licensing agreements \\
\hline \multicolumn{4}{|l|}{ 8. Entrepreneurial élan } \\
\hline \multicolumn{4}{|l|}{$\begin{array}{l}\text { 9. Reactive abilities \& } \\
\text { changeability }\end{array}$} \\
\hline $\begin{array}{l}\text { 10. Innovativeness \& } \\
\text { proactive }\end{array}$ & & & \\
\hline
\end{tabular}

Content analysis was performed on the documents (Guthrie et al, 2004). This was characterised by reading and coding contents into themes in relation to the overall research objectives specified above. The issue in each of the research objectives created a priori classification that imposed restriction on the data collection in each case. A 
manual search, as oppose to an electronic search, of the annual reports was conducted. The electronic search highlighted frequency of occurrences of particular keywords which did not convey much meaning. Thus, keywords search was combined with consideration of whole sentences. This meant that the annual report of each of the companies was read to identify chunks of meaning. This approach allowed the researchers to identify relevant new issues, as well as complex, cross case relationships, on issues linked to varieties of intellectual capital disclosed.

Table 2. Profile of the participating companies

\begin{tabular}{|c|c|c|c|c|c|}
\hline \multirow{2}{*}{$\begin{array}{l}\text { Companies and } \\
\text { Industries }\end{array}$} & \multicolumn{5}{|c|}{ Profile } \\
\hline & Nature of business & $\begin{array}{l}\text { Operating } \\
\text { period }\end{array}$ & $\begin{array}{l}\text { Total } \\
\text { staff }\end{array}$ & Total revenue* & $\begin{array}{l}\text { Market } \\
\text { share }\end{array}$ \\
\hline $\begin{array}{l}\text { Company 1: } \\
\text { Travel Agency }\end{array}$ & $\begin{array}{l}\text { Travel \& incoming } \\
\text { networks services }\end{array}$ & $\begin{array}{l}\text { Founded in } \\
2001\end{array}$ & 27 & P3.6 million & $\begin{array}{l}\text { Approx. } \\
10 \%\end{array}$ \\
\hline $\begin{array}{l}\text { Company 2: } \\
\text { Merchant Bank }\end{array}$ & $\begin{array}{l}\text { Financial Services Provider: } \\
\text { Investment banking; advisory, } \\
\text { fund management }\end{array}$ & $\begin{array}{l}\text { Founded in } \\
2012\end{array}$ & 90 & P3.4 billion & $\begin{array}{l}\text { Approx. } \\
8 \%\end{array}$ \\
\hline $\begin{array}{l}\text { Company 3: } \\
\text { 5-Star Hotel }\end{array}$ & $\begin{array}{l}\text { Lodging \& destination } \\
\text { management services }\end{array}$ & $\begin{array}{l}\text { Founded in } \\
1995\end{array}$ & 220 & P887 million & $\begin{array}{l}\text { Approx. } \\
35 \%\end{array}$ \\
\hline $\begin{array}{l}\text { Company 4: } \\
\text { Commercial Bank }\end{array}$ & $\begin{array}{l}\text { Financial Services } \\
\text { Provider }\end{array}$ & $\begin{array}{l}\text { Founded } \\
1991\end{array}$ & 1100 & P17.6 billion & $\begin{array}{l}\text { Approx. } \\
29 \%\end{array}$ \\
\hline $\begin{array}{l}\text { Company 5: } \\
\text { Regional Bank }\end{array}$ & $\begin{array}{l}\text { Property financial services } \\
\text { provider }\end{array}$ & $\begin{array}{l}\text { Founded } \\
2004\end{array}$ & 1400 & P203 million & $\begin{array}{l}\text { Approx. } \\
5 \%\end{array}$ \\
\hline
\end{tabular}

* Approximate figures

Data analysis: The analysis was done manually which gave the authors time to interact with the text. The authors coded the data into categories that corresponded to the research objectives, and the three major categories of intellectual capital: human, relational and structural capital. The analysis was guided by the IFAC classification of intellectual capital (see Table 1). Grouping of sentences/chunks of contents in the annual report was done according to the characteristics of these three dimensions of intellectual capital. The analysis process was to locate signs references of human, relational, and/or structural capital, by inspecting keywords and sentences that reflected each of the dimensions above. Where inconsistency or contradictory information was observed in the annual reports, the authors compared the data with existing literature. Where data codes did not converge, such data were omitted from the data analysis process.

To ensure consistency, a set of coding instructions were developed. Keywords and sentences were the main units of analysis, and the coding process started by first gaining familiarity with the coding rules. It was only after familiarity was achieved that sentences were identified. Key words in sentences were used to categorize sentences with intellectual capital contents. These sentences were then coded accordingly.

Data credibility: Site triangulation was a strategy used to improve data credibility. We used documents from the five different service based companies, which reduce the effect on the study of particular local factors peculiar to one service based company (Brown, 2005; Brown 2010; Brown 2014; Shenton, 2004). Equally, use was also made of peer scrutiny and member checks in which verification with fellow research colleagues helped to ensure that the ideas being captured reflected the data. These provided relatively adequate support for the credibility of the data (Yin, 2009). The findings are presented below.

\section{Results}

The analysis and iterative comparison of the data from the documents derived three types of intellectual capital that is present in the service based companies.

\section{Categories and frequency of disclosure of intellectual capital}

Consistent with the IFAC (1998) taxonomy, the companies disclosed human, structural, and relational capital assets, with the total of these disclosures across all the companies being 126 intangibles (see Table 3 ). 
Table 3. Prevalence of intangible assets disclosed by the companies

\begin{tabular}{|c|c|c|c|c|c|c|c|c|}
\hline \multirow{3}{*}{ Companies \& Industries } & \multicolumn{6}{|c|}{ Disclosure categories by frequency } & \multirow{2}{*}{\multicolumn{2}{|c|}{ Total }} \\
\hline & \multicolumn{2}{|c|}{$\begin{array}{l}\text { Human } \\
\text { Capital }\end{array}$} & \multicolumn{2}{|c|}{$\begin{array}{c}\text { Structural } \\
\text { capital }\end{array}$} & \multicolumn{2}{|c|}{$\begin{array}{c}\text { Relational } \\
\text { capital }\end{array}$} & & \\
\hline & $\mathrm{N}^{\mathrm{o}}$ & $(\%)$ & $\mathrm{N}^{\mathrm{o}}$ & $(\%)$ & $\mathrm{N}^{\mathrm{o}}$ & $(\%)$ & $\mathrm{N}^{\mathrm{o}}$ & $(\%)$ \\
\hline Company 1: Travel Agency & 7 & 25.9 & 12 & 44.4 & 8 & 29.6 & 27 & 100.0 \\
\hline Company 2: Merchant Bank & 12 & 63.2 & 4 & 21.1 & 3 & 15.8 & 19 & 100.0 \\
\hline Company 3: Five Star Hotel & 5 & 31.3 & 2 & 12.5 & 9 & 56.3 & 16 & 100.0 \\
\hline Company 4: Commercial Bank & 13 & 35.1 & 1 & 2.7 & 23 & 62.2 & 37 & 100.0 \\
\hline Company 5: Regional Bank & 17 & 63.0 & 4 & 14.8 & 6 & 22.2 & 27 & 100.0 \\
\hline Total & 54 & 42.9 & 23 & 18.2 & 49 & 38.9 & 126 & 100.0 \\
\hline
\end{tabular}

Overall, we identified human capital $(42.9 \%$, or 54 disclosures) as the most frequently disclosed category of intellectual capital asset, followed by relational capital $(38.9 \%$, or 49 disclosures). Structural capital had the least number of overall disclosures (18.2\%, or 23 disclosures). Being service based, the key resource that one expects to drive the business operations is human capital, but the emergence of structural capital, typically associated with high tech companies, was a surprising but positive development for this service sector.

\section{- Human capital assets disclosed}

Human capital relates to the knowledge, skills and experience that employees possess at work. In fact, it is interesting to note that in human capital, skills and experience were the aspects mainly referenced in the annual reports and examples of these capabilities were employee know-how, aptitudes, hard work, dedication and work-related knowledge. These qualities are composites of behavioural engagement, which is typically characterised by such traits as hard work and dedication. Thus, while behavioural engagement was evident and valued in the human resources, the human capital placed the companies in a privileged position to perform above expectations. This is no better expressed than in sentiments from two typical companies:

"Our employees have become our biggest ambassadors and champions, mirrored by our list of accolades [and employee competence] ....we have the right people for our business.... We could not have achieved all this without the hard work and dedication of our staff" [Annual Report, 2014, Company 4].

“...Our employees are a key resource in the company" [Annual Report, 2014, Company 2]

In other words, one cannot, therefore, overemphasize the necessity of employee expertise and professionalism in the form of, not just competencies, commitment, motivation and loyalty, but also know-how, technical advice, problem-solving capacity, and creativity - in the growth and expansion of these companies, and in their return on investment and capacity to learning and develop. The accolades exemplified achievement and progress made through the human resources, influenced by features of behavioural engagement.

Thus, in the company, the employees were a cherished resource. It is neither true that employees, especially those who possess the most pertinent know-how of the company, are high risk resources because they own the knowledge, nor that the knowledge that originates from these employees is not the one which matters to produce wealth, or to multiply the output of other assets and gain competitive advantage. As the examples above showed, employee commitment is able to drive company success. Both the individual and the collective knowledge of all employees in the company are vital to the overall success of the business, and it is more reinforced when the knowledge that the human resource possesses is explicit, not tacit.

The value of sharing knowledge in the company, and training employees to sustain their innovative capabilities, was referenced in the annual reports. This kind of culture therefore implies that as the companies recognise the significant value of their human capital, they also resign to the reality that individuals come and go, and in that sense, they, as companies, did not own the knowledge (human capital) per se, but could merely harness it, collectively, to drive the business. Two of the companies declared that: 
“...We are in the service industry, our business very much depend on our collective knowledge.... The sharing of knowledge is important for us, as an organisation..." [Annual Report, 2014, Company 5].

“...Within our business, people and knowledge are very important factors, resulting in our expenditure on training and other staff costs... Training to us is an investment, but we are mindful it can also be a liability, that is why we strive for 'continuous learning' to become our culture" [Annual Report, 2014, Company 1].

In human capital, then, renewal and development, which collectively are the driving forces for innovation and effectiveness in terms of return on investment in training, appear a critical bottom line for sustainability. These companies acknowledged the inherent value in developing their human resources to sustain their business.

But at the organisational level in this study, disclosure on human capital across the different companies varied. Both the Merchant Bank (63.0\%) and the Regional Bank (63.2\%) had more than 50 percent of the total intellectual capital that they disclosed being human capital, whereas the other companies had disclosure ranging between 25 and 35 percent (see Table 3). The strong emphasis on human capital in the two financial institutions, versus its de-emphasis, as evidenced in the proportion of disclosure, in the other companies provides indication that, perhaps in the Merchant Bank $(63.0 \%)$ and the Regional Bank, the human capital asset was most valued. This evidence affirms that in these service companies, managers selectively emphasized different aspects of intellectual capital, as it suits them. Thus, precisely, from the company's point of view, not only are intellectual capitals of vital importance to drive the business, but also the combination in which these assets are harnessed, deployed, and used in order to add value.

The evidence abovementioned suggests then that if companies are to gain and sustain a competitive edge in an often dynamic and fast changing market environment that demands the identification and strategic utilisation of competitive drivers, and/or their subtlest policies, they need to rely on their strongest knowledge or on their company-specific intellectual capital.

\section{- Relational capital assets disclosed}

Relational capital is quite distinct from human capital, as unlike the latter, the former is about the encounters and interactions with stakeholders, which for the companies sampled were largely customers and suppliers. The kind of relational capital cited by the companies ranged from the company brand and its influence in the market, through to satisfaction in customer feedback. It also included the suppliers and their links and feedback to the business. The following excerpts illustrated the vital importance of the relationship that prevails between the companies and their stakeholders, plus the views that stakeholders held about the entities:

“...our suppliers are an important source of new ideas, innovation and support..." [Annual Report, 2014, Company 1]

“...We manage carefully our relationships with customers, and we take this process seriously... our clients hold perceptions of us, which they link to our brand; they stay loyal to the brand. We manage this relationship by ensuring that our customers continue to hold positive perceptions about us" [Annual Report, 2014, Company 4].

Unlike other types of intellectual capital, relational capital forces the companies to think external, i.e., to customers, suppliers, creditors. The shift in attention to the external environment drove highly competent and shrewd managers to not only tap into the wealth of knowledge and innovative feedback from their own customers and suppliers, but to also understand their needs. For instance, Company one (1), which operated in the travel and tourism business (Table 3 ), valued their interactions with suppliers as source of ideas, whereas Company four (4), which operated in the financial services (Table 3), valued and protected their relationship with customers, especially because they associated satisfaction with brands. Thus, different self-interest related motives drove the companies to value relational capital.

Frustrated managers often do not recognize that they can tap into the wealth of knowledge from their own customers and suppliers. Equally, astute and effective managers, with deep understanding of the strategic and competitiveness value of relational capital as an intangible asset, can deemphasize it, to focus on other types of intellectual capital which contributes greater value for the company. It is hardly surprising then that different frequency of disclosure of relational capital emerged in the annual reports. Both the Commercial Bank and the 5-Star Hotel stressed relational capital, as evidenced in the relatively higher disclosure. These companies had more than 50 percent of their total intellectual capital disclosed being relational capital, whereas in the other companies disclosure ranged between 15.8 and 29.6 percent (Table 3). Cursorily, relational capital was not as important as the other types of intellectual capital for the Regional Bank (22.2\%), and the Merchant Bank (15.8\%), which both emphasized human capital instead, nor 
for the Travel Agency (29.6\%) which stressed structural capital. The companies concentrated on those intellectual capitals which contributed greater value for the business.

The explicit acknowledgment by the company that they "...carefully [manage] the relationships..." affirmed the significance of the external capital. But if one were to judge from some characteristics inherent to relational capital such as satisfaction, loyalty, and longevity of relationships, which have proved to be as dynamic as they are controversial - then it would be reasonable to expect that there must be something which forcefully maintains a balance, if not strategically, at least philosophically, in the external relationships between the company and its stakeholders in order for both parties to remain interested in the relationship.

A key auxiliary motive for investigating relational capital reporting in the companies sampled was not just to gain insights into its frequency of disclosure but also to extract words or phrases that convey meanings, implicitly or explicitly, that can best clarify and illustrate a reliably comprehensive view with regards to why relational capital, as an external asset, is an essential resource for, and within, the business. Already, as indicated earlier, we found sentiments that give hint as to why the companies are keen about maintaining external capital but these have largely been self-interest motives from side of the companies only; such as valuing the suppliers for their ideas and valuing customers in order to grow the business.

In addition to those, we found references to key words that suggest why and how the companies sustained their relational capital and remained interested in the relationship. For instance, words like centricity, trust, loyalty, satisfaction, communication, and quality were used frequently in the annual reports:

“...As we endeavour to create an organisation whose name and brand is synonymous with innovative and superior customer service, embedding a strong culture of customer centricity will continue to be a major focus." [Annual Report, 2014, Company 3].

"The introduction of this trusted diversified financial brand in Botswana has further broadened our corporate and investment offering and helped us sharpen our competitive edge... our segmentation model have made us a trusted authority... Our customers trust us; they know we are a highly trusted brand. Our brand speaks to differentiation in the market. It speaks to service, it is reputable. Customers know they can trust our wealth managers and that they are dealing with highly knowledgeable people." [Annual Report, 2014, Company 4].

In other words, to sustain external relationships, managers in both the Merchant Bank and the 5-Star Hotel, in particular, resorted to building mutual dependency, responsiveness, and trust between the company and its external stakeholders. 'Trust' conveys a sense of environmental uncertainty but at the same time it is linked to reputation and satisfaction in the relationship. A relationship of trust supports knowledge transfer and value creation. In the Commercial Bank (Company 4), in particular, trust and reputation were paramount yet simultaneously interlinked. It may very well be that the company recognizes that the absence of trust drives customer away, hurts reputation, and gives no competitive advantage. The emphasis on trust and mutual dependency conceivably allowed the companies to extract otherwise tacit knowledge from their customers, and promoted information sharing.

It is however interesting to note that in the process of building relational capital, the companies drew on their human capital, e.g., 'highly knowledge people' as internal resources. This point acknowledges that not only are trust and mutual dependency vitally important for building and maintaining strong relational capital, but that the human and relational capital are inseparable; the people construct and sustain the relationships.

There was room, also, for what could be seen as the promise of quality and satisfaction from the company points of view. Customer satisfaction, quality of service delivery and mutual benefits appear to play a directive role in strengthening relational capital and consequently the long term development of external relationships. Among the banks, a typical excerpt was:

"...The growth of the business segment portfolio is centred on strategic relationships with both clients and suppliers. The strategy for the portfolio continues to be centred on point of sale and through long-standing and mutually beneficial relationships with key industry players... [And] improving the quality, reliability and efficiency of our channels... The Board assures its stakeholders that the Bank maintains adequate capital reserves to support the nature and extent of its risk exposure." [Annual Report, 2014, Company 4].

The directive role of 'quality' and of 'mutual benefit' is evident. In other words, while the company developed a culture of explicitly locating its self-interest in the external relationship, it simultaneously considered the needs and interest of its external stakeholders, i.e., clients and suppliers as well. In the world of business, aspects of stakeholder 
needs often include responding promptly to queries, whether or not contractual obligations are maintained as initially agreed, prompt attention from the company once a problem arises, value for money, as well as reliable, and quality service. On the other hand, industry's interest in relational capital, as explicitly hinted at in the excerpt above, is largely efficiency, market access and growth.

The Commercial Bank (i.e., Company 4) which mainly disclose on relational capital, further cited the value of customers (customer capital), the dedication to reduce customer complaints, deepening the relationship with clients and acknowledged the support from loyal customers. In contrast, the 5-Star Hotel focused largely on branding and improving its image - this occurred largely at a time when the company was going through a rebranding exercise. Although there were companies in this study which deemphasized relational capital (Company 1,2 and 5), they nevertheless referenced the relationship, citing, for instance, supplier capital, stating: “...Our suppliers are an important source..." (Company 5: Regional Bank) and reputation and branding (Company 1: Travel Agency). Thus, the central role of the customers as a source of value in the external relationship was a common thread that tied all the companies together. No doubt, as the cooperating parties learn to recognize the strengths of the other and as they try to exploit these for common benefits, they collectively, and individually, strengthen their relational capital.

\section{- Structural capital assets disclosed}

In contrast to human and relational capital, structural capital was the least (18\%) disclosed type of intellectual asset (see Table 3). Structural capital represents the knowledge endowed within, and generally 'owned' by, the company, as a result of its acquisition externally, or it development from the internal structures and people in the company. While these capitals are intellectual property rights and infrastructure assets, by which the company defines work processes and add value to their business, we found in this study that the service based companies disclosed solely infrastructure assets. For instance:

“... [We] acknowledge the importance of having the right organisational culture and people to enable it to deliver on its brand promise to customers. By asking our stakeholders, including our employees, 'How can we help you?', we seek to affirm our reputation as a helpful bank, internally and externally" [Annual Report, 2014, Company 4].

In this case, both the corporate culture and management philosophy, as infrastructure assets, were emphasized. The corporate culture is the sum of individual shared mindsets, customs, opinions, values, and norms within the company, and it is this collective spirit that helps to define the management philosophy and the ways it seeks to achieve its goals. While most part of corporate culture is invisible (e.g., implicit values and assumptions) and only a portion visible (i.e., practices), the company culture and employees are interdependent, for it is the people in the company who create, sustain, practice, and transform the culture, and it is they, who, in turn act to attain the corporate strategy. This point, evidently recognised and acknowledged in the excerpt from Company 4 above, drove that entity to strengthen its processes and appropriately align its corporate culture to customer requirements and to deliver on its brand promises.

Interestingly, the Regional Bank and the Merchant Bank positioned themselves to build a competitive advantage directly through their management processes and information systems, respectively, and characterized themselves as being businesses that operate in the interest of customers. The Regional Bank invested in its internal control structures as part of its management processes to boost efficiency, whereas the Merchant Bank stressed its reach through information systems. These process capitals were typically reported as follows:

“...The Bank has established and maintained ... appropriate and effective internal control structure in order to monitor the Bank's continued compliance with internal policies and procedures... an independent Internal Audit function is in place within the Bank ...to improve the effectiveness of the Bank's risk management, control and governance processes" [Annual Report, 2014; Company 5].

“...We are simplifying our products and processes to help achieve an efficient IT infrastructure, an effective organisation, and a streamlined back office. IT is helping to get our operational processes and our risks where we want them to be. We have set ourselves the following IT goals: - Enhancement of our online offering to our clients through new services and interaction, - Ongoing digitisation and automation of working processes, - Migration to fewer and cheaper IT platforms and applications" [Annual Report, 2014; Company 2].

Infrastructure assets such as management processes and ICT proved immensely valuable for these companies. Management process involves goal setting, planning, and controlling of activities, leading to their execution. While management process is, understandably, an essential function in each of these companies, it appears to have been 
prioritized in the Regional Bank, not just to demonstrate its capabilities to meet market requirements but also to protect and to optimize its corporate resources. The Regional Bank disclosed on internal control, as its core management process activity, to ensure compliance with policies and procedures. In other words, internal control was pivotal to the Bank's reputation to being the guardian of responsible and sustainable investment. This position is consistent with the wider role of management process activities, which is to reduce costs, enhance efficiency and productivity, and minimize errors and risks.

But technology was also employed to boost efficiency. As infrastructure assets, ICT and information systems were disclosed but this was mainly valued by the Merchant Bank. From the abovementioned excerpts, it appears that although ICT is an important tool to reduce costs and improve performance internally and in relation to investment partners, the Merchant Bank's strategy to enhance online offering and to digitise and automate working processes improved its ability to respond to customer needs, and to increase competitiveness.

But notwithstanding the emerging issues above, the wider argument around structural capital is that as infrastructure asset gains prominence, and as efforts are made to achieve IT infrastructure efficiency in companies, broadly, investment in these structural capitals serves ultimately as substitute for labour. In other words, increase reliance on IT infrastructure and information system capital concurrently diminishes the demand for human capital. In the Banks above, for instance, ordinary financial services are being standardized, and customers are being permitted to perform basic financial services online. This situation places human and structural capital in tension; high disclosure on the latter shrinks the need for the former and erodes, in particular, job tenure and creation.

All the same, IT infrastructure and information system capital give the companies a competitive edge, as a whole. Typical sentiments were:

“...[We] take the right measures to ensure that both our client data and corporate data are adequately protected and recoverable. Information security contributes to the protection of client and corporate information [both automated and manual] processed within the bank" [Annual Report, 2014; Company 2].

“...Managing our relationships with customers is a key focus area ... Our customers trust us... they know we at the cutting edge of business processes" [Annual Report, 2014; Company 4].

"...Banking users now have a platform to conduct day to day banking transactions on the go, [using] Smartphone Banking App. Customers can use the Smartphone Banking App to buy electricity, receive cash from e-wallet, top up on airtime, and communicate with their relationship manager..." [Annual Report, 2014; Company 5].

All these excerpts hinted that ICT infrastructure is being used to drive service innovation, by transforming traditional processes and relationships. Technology was treated as a tool to manage customer relationship and risks, but customer relationship management is more than just technology. Rather, it is a holistic tactic to a company's philosophy of dealing with its clients. As we have seen from the excerpts presented above, this includes brand and reputation, service to customer, data protection policies and processes, innovation systems, and the management of information. In addition, Smartphone Banking technology, for instance, has forced the Regional Bank to invest in the renewal of its online platform to meet clients' expectations. Thus, structural capital helps to build strong relational capital, and at the same time, offers a dynamic environment in which the human capital is able to innovate.

The Travel Agency (Company 1) had more disclosure on structural capital (44.4\%) than all the other companies (see Table 3). But unlike the other companies, the Agency mainly disclosed on knowledge sharing, as exemplified by the following quote: “...through caring for, educating and empowering people... building sustainable conservation economies." Although there is no specific study of intangibles disclosure in the tourism industry in Botswana, one can only specular that the disclosure on knowledge sharing might be linked to a management philosophy which recognised that, as a company, they cannot achieve sustainable conservation economies alone but rather, the onus lays also on the wider community. In this sense, the annual report was merely used, out of necessity, to communicate and to share knowledge about sustainable conservation with stakeholders.

The second commonest disclosure in the Travel Agency was relational capital, with slightly more than a quarter (29.6\%) of the total disclosure. This observation too illustrates the interrelations between structural and relational capital. The value of relational capital in a travel agency situation is high, and it is understandable that these forms of intellectual capital emerged as popular. 


\section{Further Discussion}

\section{Multiple motives for disclosure}

According to literature, voluntary disclosure of intellectual capital assets may be triggered by an attempt to increase the liquidity of the shares of a company (Schuster \& O'Connell, 2006), or to enhance the credibility of the company and reduce its risk of job loss (Adina \& Ion, 2008). Still further, it may be motivated by an attempt to avoid litigation for inadequate and untimely disclosure (Heitzman, Wasely \& Zimmerman, 2010). However, our research found none of these reasons to motivate disclosure. Our findings suggest that disclosure was possibly linked to efforts to send signals to the markets (Kang \& Gray, 2011) and a need to reduce information asymmetry between the managers and shareholders in these listed companies (Hossain \& Hammami, 2009). Information asymmetry is bad for a company as the cost of capital escalates in such situation (Subhas \& Vishakha, 2011).

But the policy environment in Botswana has supported and motivated intellectual capital development, as extensive efforts are underway at a political level to enhance innovation through the country's innovation hub, and to acquire and develop global brands (BITC, 2014). Alongside this effort, there is the national policy agenda which sets as its priority "for the nation to become a knowledge society" (MoESD, 2008:1). Human capital development is pivotal to achieve these aims. These sentiments also may have a tacitly influence on the disclosure patterns.

\section{Varieties of intellectual capital disclosed}

Our research has shown that all the service-based companies sampled actively disclosed three forms of intellectual capital: i.e., human capital, relational capital, and structural capital but in different proportion, regardless of the nature of their business. Taken together, these findings show substantial similarity among the service companies, though operating in quite diverse circumstances as well as having some important variation by company size, leverage, profitability, and service orientation. The common areas of disclosure seems to reflect a recognition of the interlinkages among the components of intellectual capital (De Santis \& Giuliani, 2013).

Yau, Chun, and Balaraman (2009) as well as De Santis and Giuliani (2013), assert that despite human capital generally viewed as the initiator of intellectual capital, companies tend to dsclose more about their structural capital, with human capital being the least disclosed. However, we found a different scenario. Only one of the five companies sampled had structural capital as the most disclosed asset. This occurred in the travel and tourism industry, which was surprising because structural capital, according to Sonnier (2008), is typically associated with technology based companies. A possible explanation for the high disclosure on structural capital in the travel and tourism business in Botswana is that, may be the company has recognised that it cannot achieve sustainable conservation economies alone. Consequently, the company may have considered it prudent to use the annual report as a communication device for knowledge sharing with stakeholders, including the political establishment.

All the same, in the remaining four companies, two had human capital, and the other two had relational capital, respectively, as the most disclosed asset. None of the companies disclosed on intellectual property, which is part of structural capital. The authors believe that the differentiated emphasis in the disclosure patterns may well be a result of converging forces: i.e., (a) a sustained effort by these companies to increase their unique value and gain competitive advantages in a changing wider financial and tourism/hospitality business environment in Botswana (WTTC, 2014), and (b) low motivation by the companies to develop intellectual property since they are part of multinational cooperations.

But the fact that human and relational capital were the most frequently disclosed intellectual capital was not a surprise. Human capital is the main resource in service-based companies, as employees are pivotal to the delivery of services (Möller et al, 2011). In developing economy like Botswana's, the tourism/hospitality and banking industry still rely extensively on employees to ensure that their customer needs are met. Thus, our finding reaffirms the expectation for the sector and illustrates that the efforts of employees are still highly valued.

But one would have expected a more widespread disclosure on human capital characteristics, if at least the reason advanced by Yau, Chun and Balaraman (2009) who asserted that human capital development is an essential ingredient for the future competitiveness of service companies. Perhaps additional incentives, or regulations, beyond the current tax levy for training, need to be implemented as part of the 'developmental state' posture (Joshi, 2012).

\section{Conclusions and Implications}

Conclusions: The study established that, in the dynamic business context in which they operated in Botswana, the service based companies disclosed three varieties of intellectual capital assets - human, structural and relational capital. The disclosure is perhaps initial signs that the companies were cognisant of these capitals. The motives for 
disclosing the intellectual capital appear linked to many factors, including an attempt to increase the unique value of the company in order to send signals to the markets, and to minimize negative impact. The motives also appear tacitly to reflect a corporate reawakening to participate in Botswana's human capital development.

Implications: Intellectual capital needs to be seen as a priority in the service-based companies. To demonstrate this, reporting on intellectual capital needs to become a prominent part of annual reports. Under the prevailing reporting practices, intellectual capital reporting is constrained and downplayed. Until this practice is corrected, the real value of these companies is likely to remain incomplete.

As Botswana service economy develops, the need to value intellectual capital is likely to grow. Consequently, the need for a structured and systematic measurement and valuation of intellectual capital is likely to become a greater demand on managers. More use needs to be made of techniques such as capability profiling and competency mapping to manage human capital. Serious management socialisation of the interconnection of the varieties of intellectual capital is needed in order to take full advantage of the intellectual capitals. Finally, maximizing the intellectual capitals in the company means that there is need for the development and implementation of bespoke intellectual capital value drivers. But implementing such a process is often easier said than done, and this represents a key challenge for managers.

\section{References}

Adina, P., \& Ion, P. (2008). Aspects regarding corporate mandatory and voluntary disclosure. Annals of the University of Oradea: Economic Science, 3(1), 1407-1411.

AEO. (2012). Botswana 2012. Retrieved from www.africaneconomicoutlook.org

$\begin{array}{llllll}\text { Annual } & \text { Report. } & \text { (2014). } & \text { Company } & \text { Retrieved }\end{array}$ http://wildernesstrust.com/reports/Trust-Annual-Report-2014.pdf

Annual Report. $\quad$ (2014). $\quad$ Company 4.4 Retrieved https://www.fnbbotswana.co.bw/downloads/fnbBotswana/annual/FNBBAR2014.pdf

$\begin{array}{llllll}\text { Annual } & \text { Report. } & \text { (2014). } & \text { Company } & \text { Retrieved }\end{array}$ https://corporate.vanlanschot.nl/media/1518/2014-annual-report-p51.pdf

Annual Report. (2014). Company $3 . \quad$ Retrieved from http://www.peermont.com/investor-information/financial-reports

$\begin{array}{llllll}\text { Annual } & \text { Report. } & \text { (2014). } & \text { Company } & \text { 5. } & \text { Retrieved }\end{array}$ http://www.bancabc.com/media/10838505/abc\%20holdings\%20ar'14\%20-\%20web.pdf

Beddi, H., \& Mayrhofer, U. (2010). The role of location in headquarters-subsidiaries relationships: An analysis of French multinationals in emerging markets. Proceedings of the 36th Annual EIBA (European International Business Academy) Conference, December 2010, Portugal.

BICA. (2013). GAAP in Botswana for entities not applying IFRS. Gaborone: BICA.

BITC. (2014). Annual Report of the Botswana Investment and Trade Centre.

Bontis, N., \& Fitz-enz, J. (2002). Intellectual capital ROI: A causal map of human capital antecedents and consequents. Journal of Intellectual Capital, 3(3), 223-47.

Bontis, N., Keow, W., \& Richardson, S. (2000). Intellectual capital and business performance in Malaysian industries. Journal of Intellectual Capital, 1(1), 85-100.

Brown, B. (2005). The incorporation of poverty into adult identity over time: Implications for adult education. International Journal of Lifelong Education, 24(5), 393-404.

Brown, B. (2010). Social hostility and the "dropout" syndrome: Leadership assisting youths' re-entry into school? Educational Review, 62(1), 53-67.

Brown, B. (2014). Strategies to achieve congruence between student chronological age and grade placement in the compulsory phase of education in Botswana. Journal of Education and Learning, 3(3), 76-94.

Brüggen, A., Vergauwen, A., \& Dao, M. (2009). Determinants of intellectual capital disclosure: Evidence from Australia. Management Decision, 47(2), 233-245.

Canadian Institute of Chartered Accountants. (2001). Management's discussion and analysis: Guidance on preparation and disclosure - review draft. Canadian Institute of Chartered Accountants. 
Carrell, J. (2007). Intellectual Capital: An Inquiry into its acceptance. Business Renaissance Quarterly. Retrieved from https://www.questia.com/library/journal/1P3-1268767091/intellectual-capital-an-inquiry-into-its-acceptance

Choong, K. (2008). Intellectual capital: definitions, categorization and reporting models. Journal of Intellectual Capital, 9(4), 609-638.

CIMA. (2009). Understanding corporate value: Managing and reporting intellectual capital. Cranfield University, Cranfield School of Management.

Creswell, J. W. (1994). Research design: Qualitative and quantitative approaches. Thousand Oaks, CA: Sage.

Creswell, J., \& Garrett, A. (2008). The "movement" of mixed methods research and the role of educators. South African Journal of Education, 28, 321-333.

De Santis, F., \& Giuliani, M. (2013). A look on the other side: Investigating intellectual liabilities. Journal of Intellectual Capital, 14(2), 212-226.

Edvinsson, L., \& Malone, M. (1997). Intellectual Capital. London: Piatkus.

Engstro"m, T., Westnes, P., \& Westnes, S. (2003). Evaluating intellectual capital in the hotel industry. Journal of Intellectual Capital, 4(3), 287-303.

Ezekwesili, O. (2012). Achieving knowledge based education in a natural resource dependent economy. Being a speech delivered on the occasion of the 12th University Of Botswana Foundation annual fundraising and gala dinner. Gaborone, Botswana. August 31, 2012.

Firer, S. (2005). Using intellectual capital as a success strategy in South Africa. South African Business Review, 9(1), $1-20$.

FRC. (2014). FRC ARP staff research report: Investor views on intangible assets and their amortization. London: The Financial Reporting Council.

Guthrie, J., \& Petty, R. (2000). Intellectual Capital: Australian annual reporting practices. Journal of Intellectual Capital, 1(3), 241-251.

Guthrie, J., Johanson, U., Bukh, P.N. \& Sa'nchez, P. (2003). Intangibles and the transparent enterprise: new strands of knowledge. Journal of Intellectual Capital, 4(4), 429-40.

Guthrie, J., Petty, R., \& Johanson, U. (2001). Sunrise in the Knowledge economy: Managing, measuring and reporting intellectual capital. Accounting, Auditing and Accountability Journal, 14(4), 365-382.

Guthrie, J., Petty, R., Ferrier, F., \& Wells, R. (1999). There is no accounting for intellectual capital in Australia: A review of annual reporting practices and the internal measurement of intangibles within Australian organisations, OECD Conference Report, Amsterdam, June.

Guthrie, J., Petty, R., Yongvanich, K., \& Ricceri, F. (2004). Using content analysis as a research method to inquire into intellectual capital reporting. Journal of Intellectual Capital, 5(2), 282-293.

Hall, P., \& Soskice, D. (Eds.). (2001). Varieties of Capitalism: The Institutional Foundations of Comparative Advantage. New York: Oxford University Press.

Heitzman, S., Wasely, C., \& Zimmerman, J. (2010). The joint effects of materiality thresholds and voluntary disclosure incentives on firms' disclosure decisions. Journal of Accounting and Economics, 49(1-2), 109-132.

Hossain, M., \& Hammami, H., (2009). Voluntary disclosure in the annual reports of an emerging country: The case of Qatar, Advances in Accounting, incorporating Advances in International Accounting, 25(2), 255-265.

IFAC. (2009). Measurement and management of intellectual capital. Birmingham: IFAC.

Joshi, D. (2012). Varieties of Developmental States: Three Non-Western pathways to the millennium development goals. Journal of Developing Societies, 28(3), 355-378.

Kang, H., \& Gray, S.J. (2011). Reporting intangible assets: Voluntary disclosure practices of top emerging market companies. The International Journal of Accounting, 46(4), 402-423.

Kianto, A., Hurmelinna-Laukkanen, P., \& Ritala, P. (2010). Intellectual capital in service- and product-oriented companies. Journal of Intellectual Capital, 11(3), 305-325. http://dx.doi.org/10.1108/14691931011064563 
Kwon, D.B. (2009). Human capital and its measurement. 3rd World forum on Statistics, Knowledge and Policy: Charting Progress Building Visions, Improving Live. Busan, Korea, October 27-30.

Lange, G.M. (2004). Wealth, natural capital, and sustainable development: Contrasting examples from Botswana and Namibia. Environment and Resource Economics, 29, 257-283.

Lee, J. (2011). Incremental innovation and radical innovation: the impacts of human, structural, social and relational capital elements. Doctor of Philosophy Dissertation. Michigan State University.

Lekone, B., \& Mukuna, J. (2014). Statutory and corporate governance concerns on investments by pension funds in Botswana. European Scientific Journal, 10(19), 193-202.

Lev, B., \& Zarowin, P. (1999). The boundaries of financial reporting and how to extend them, Journal of Accounting Research, 37(2), 353-385.

Lim, L., \& Dallimore, P. (2004). Intellectual capital: Management attitudes in service industries. Journal of Intellectual Capital, 5(1), 181-94.

MaClure, B. (2015). Intangible assets provide real value to stocks. Retrieved August 2015, from http://www.investopedia.com/articles/03/010603.asp

Maree, K. (2001). Valuation of intellectual capital in South African companies: A comparative study of three valuation methods. Master of Commerce dissertation. Rhodes University.

Marr, B., Gray, D., \& Neely, A. (2003). Why do firms measure their intellectual capital? Journal of Intellectual Capital, 4(4), 441-64.

Meritum Project. (2002). Guidelines for the measurement and disclosure of intangible assets. Retrieved June 2014, from http://www.fek.su.se/home/bic/meritum/download/Guidelines.rtf

Merriam, S. B. (1998). Qualitative research and case study applications in education. San Francisco: Jossey-Bass.

MoESD. (2008). Situation analysis of tertiary education and training in Botswana. Ministry of Education and Skills Development. Gaborone: Botswana.

Möller, K., Gamerschlag, R., \& Guenther, F. (2011). Determinants and effects of human capital reporting and controlling. Journal of Management Control, 22(3), 311-333.

Msweli, P. (2015). Human capital development: What can South Africa learn from Botswana? Environmental Economics, 6(1), 144-151.

Mundi. (2014). Botswana Economy Profile 2014. Retrieved August 2015, from http://www.indexmundi.com/botswana/economy profile.html

Namasivayam, K., \& Denizci, B. (2006). Human capital in service organizations: Identifying value drivers. Journal of Intellectual Capital, 7(3), 381-93.

OECD. (2010). New sources of growth: Intangible assets. Retrieved August 2015, from http://www.oecd.org/sti/inno/46349020.pdf

OECD. (2012). Corporate reporting of intangible assets: A progress report. Retrieved August 2015, from http://www.oecd.org/daf/ca/Intangible\%20Assets.pdf

Ordonez de Pablos, P. (2004). The importance of relational capital in service industry: The case of the Spanish banking sector. International Journal of Learning and Intellectual Capital, 1(4), 431-40.

Perini, F., \& Vurro, C. (2010). Corporate sustainability, intangible assets and competitive advantage. Symphonya. Emerging Issues in Management, 2, 1-8.

Petty, R. (2003). The correlation between the voluntary disclosure of intellectual capital indicators and financial success. Working paper delivered to a conference of the Citigroup Global Consumer and Investment Bank (Hong Kong), August 2003.

Pienaar, J., \& Du Toit, A. (2009). Role of the learning organisation paradigm in improving intellectual capital. Journal of Contemporary Management, 6(1), 121-137.

Roodt, M. (2011). Intellectual capital characteristics for competitive advantage: Case study of a multinational corporation. Dissertation: Master of Business Leadership. Pretoria: UNISA. 
Schuster, P., \& O'Connell, V. (2006). The trend toward voluntary corporate disclosures. Management Accounting Quarterly, 7(2), 1-9.

Sen, A. (2003). Human capital and human capability. In Sakiko Fukuda-Parr and A.K. Shiva Kumar (eds.), Readings in Human Development (2nd ed.). New York: Oxford University Press.

Shenton, A. (2004). Strategies for ensuring trustworthiness in qualitative research projects. Education for Information, 22, 63-75.

Sonnier, B.M. (2008). Intellectual capital disclosure: High-tech versus traditional sector companies. Journal of Intellectual Capital, 9(4), 705-722.

Stewart, T. (1997). Intellectual Capital. New York, NY: Bantam Doubleday Dell Publishing Group.

Subhas, C., \& Vishakha, M. (2011). A study on intangible assets disclosure: An evidence from Indian companies. Intangible Capital, 7(1), 1-30.

Sullivan, P. (1998). Profiting from Intellectual Capital. New York: John Wiley \& Sons, Inc.

Willem te Velde, D., \& Calì, M. (2007). Assessment of Botswana's services sector: A study for the BTPP/BIDPA. Overseas Development Institute.

WTTC. (2014). Travel and Tourism Economic Impact 2014: Botswana. The World Travel and Tourism Council, Harlequin Building, 65 Southwark Street, London: WTTC.

Yau, F., Chun, L., \& Balaraman, R. (2009). Intellectual capital reporting and corporate characteristics in publiclisted companies in Malaysia. Journal of Financial Reporting and Accounting, 7(1), 17-35.

Yin, R. (2009). Case study research: Design and methods (4th Ed.). Thousand Oaks, CA: Sage. 